\title{
Allocative Efficiency Model of Shrimp Culture Enterprise Input in Muara Badak Regency, Kutai Kartanegara
}

\author{
Nurul Ovia Oktawati ${ }^{\# 1}$, Etik Sulistiowati $N^{* 2}$ \\ Faculty of Marine and Fisheries, University of Mulawarman \\ Samarinda, Indonesia \\ ${ }^{1}$ nurul.ovieedyahoo.com \\ 2etiksnegmail.com
}

\begin{abstract}
The aim of this study is analyzing allocative efficiency on production factors usage on shrimp culture enterprise and analyzing the revenue of shrimp enterprise in Muara Badak Regency. The study used Cobb-Douglas Production function analysis by using Multiple Regression Analysis. Net Product Marginal was used to know allocative efficiency. The analysis result showed that NPMx/px value [ki] of seeds and fertilizer variable was greater than $1,4.65$ and 3.13 respectively. Allocatively, production factors which are used on pond culture enterprise in the location of study was not efficient yet. In order to increase production and revenue, it is needed to do an optimum addition on seed and fertilizer inputs. For seeds, it needed an addition about 22.000 tails per hectare and $11 \mathrm{~kg}$ additional fertilizer for each hectare. Economically, this enterprise was reasonable to be undergone based on RCR indicator 2,35 point. It means that the benefit of pond enterprise in Muara Badak Regency is 2,35 bigger than its cost. We recommend to optimize production cost by maximizing the usage and process of production cost precisely.
\end{abstract}

Keywords - Allocative Efficiency, Pond, Shrimp, Muara Badak

\section{INTRODUCTION}

\section{A. Background}

Basically, fishery development is people effort to gain the benefit from natural resources of fishery; culture enterprise is one of such effort. The main principle of improving pond enterprise productivity is appropriateness in management. Such management including on how fish farmer uses their capability to coordinate production factors usage wisely and be able to produce as it expected. Effeciency, productivity, and economic activity measurement are highly important as indicators between differences of input have been used and outputs have been generated.

Efficiency concept is emerged based on the assumption of 'the resources for fulfilling human desire is unlimited', thus it is encouraged to produce the largest output with the smallest input.
Shrimp pond enterprise is one of fishery resources usage in Muara Badak, Kutai Kartanegara Regency related to community economic activity.

Efficiency, productivity and economic activity measurement is very important to indicate the gap between input and output. The process of input allocation (production factors) to maximize production can be attempted through deciding what are the steps which will be considered to gain optimum economic efficiency, that eventually will improve fish farmer revenue.

\section{B. The aim of study}

- To analyze allocative efficiency of production factors usage on shrimp culture enterprise in Muara Badak, Kutai Kartanegara Regency.

- To analyze shrimp pond fish farmer revenue in Muara Badak, Kutai Kartanegara Regency.

\section{Study benefit}

The study result is expected to be one of the breakthrough on sustainable shrimp pond enterprise productivity enhancing in term of allocative efficiency in Muara Badak, Kutai Kartanegara Regency.

\section{RESEARCH METHODOLOGY}

\section{A. Sampling Method}

The population in this study is all of fish farmers who live in the research location. Furthermore, either sampling method or respondent samplings were purposive sampling. It defines as unrandomized sampling based on some consideration where chosen sample is fish farmer 
who have productive pond, through direct interview technique.

Efficiency test is used to find whether input or production factors used in shrimp pond culture in Muara Badak, Kutai Kartanegara were efficient or were not efficient yet. Term of efficiency used in this study define as allocative efficiency (price). Efficiency is a process of using smallest input to to gain the biggest products. Price efficiency is reached if there is an equal ratio between marginal productivity value (NPMx) and input cost (Px) [7]. Mathematically can be wrote down as follow:

$$
\begin{aligned}
& \text { NPMx }=\text { Px atau } \\
& \text { NPMx/Px=1 } \\
& \text { bYPx/x=Px atau bYPx/(x.Px) } \\
& \text { Which is: } \\
& \mathrm{b} \quad=\text { elasticity } \\
& \mathrm{Y} \quad=\text { production } \\
& \mathrm{Py} \quad=\text { product price of } \mathrm{Y} \\
& \mathrm{X} \quad=\text { production factors numbers } \\
& \mathrm{Px} \quad=\mathrm{X} \text { production factors price }
\end{aligned}
$$

If $\mathrm{NPMx} / \mathrm{Px}>1$ so input usage did not efficient yet. To be efficient, input $x$ should be added NPMx/Px $<1$. Thus, $x$ usage input does not efficient. To be efficient, $x$ input should be lessened. Price efficiency could be reached if the ratio of marginal productivity value of each input (NPMxi) and it input price (Vi) or "ki" is equal to 1 [9]. This condition prerequisite the equality between NPM and production factor price.

\section{Revenue Analysis}

\section{A. Cost Analysis}

In the analysis of variabel cost -including seeds, pestiside, and labour-, total cost is the sum up of fixed and variable cost. Mathematically could be revealed as follow:

$$
\mathrm{TC}=\mathrm{FC}+\mathrm{VC}
$$

Which is:
$\mathrm{TC}=$ Total Cost
$\mathrm{FC}=$ Fixed Cost
$\mathrm{VC}=$ Variable Cost
B. Revenue

Revenue is all kinds of revenue which have been accepted from product selling. Those statement could be determined in this formula:

$$
\begin{aligned}
& \mathrm{TR}=\mathrm{P} \times \mathrm{Q} \\
& \text { Which is: } \\
& \mathrm{TR}=\text { Total Revenue }(\mathrm{Rp}) \\
& \mathrm{P}=\text { Product price }(\mathrm{Rp}) \\
& \mathrm{Q}=\text { Quantity of product }
\end{aligned}
$$

\section{Revenue}

The revenue of shrimp pond enterprise is defined as the gap between crude shrimp pond enterprise revenue and total expenses of shrimp pond enterprise. The revenue could be formulated as follow:

$$
\begin{aligned}
& \pi=\mathrm{TR}-\mathrm{TC} \\
& \text { Which is: }
\end{aligned}
$$

$$
\begin{array}{cl}
\pi= & \text { the revenue of shrimp pond } \\
\text { enterprise }(\mathrm{Rp}) & \\
\mathrm{TR}= & \text { Total Revenue }(\mathrm{Rp}) \\
\mathrm{TC}= & \text { Total Cost }(\mathrm{Rp})
\end{array}
$$$$
\text { RC Ratio analysis }
$$

$\mathrm{RC}$ ratio analysis (Revenue Cost Ratio) is a comparation between total revenue and total production cost, mathematically:

\section{$\mathrm{RC}$ ratio $\mathrm{TR} / \mathrm{TC}$}

Such analysis shows the rate of economic efficiency of shrimp pond enterprise. This efficiency criteria will be reached if:

$\mathrm{RC}$ ratio $>1$ means the shrimp pond enterprise is beneficial

$\mathrm{RC}$ ratio $=1$ means the shrimp pond enterprise is both beneficial and lose

$\mathrm{RC}$ ratio $<1$ means the shrimp pond enterprise is lose

\section{RESULT AND DISCUSSION}

\section{A. The Overview of location of study}

Muara badak is one of local government administration under Kutai Kartanegara Regency. Its area covers $1.045 \mathrm{~km}^{2}$ in the hill and mountain area on the elevation of $2.000 \mathrm{~m}$ sea surface.

- The Northern area is boardened with Kecamatan Marang Kayu

- The Eastern area is baordened with Selat Makassar 
- The Southern area is boardened with Kecamatan Anggana

- The Western area is boardened with Kecamatan Tenggarong Seberang

Muara Badak's climate is affected by high rainfall of wet tropic climate. The highest number of rainfall is 168 days (46\%) or $1.687 \mathrm{~mm}$ in a year.

\section{B. Fish farmer Household Profile}

Muara Badak is located in 1170 07' - 1170 32' of Eastward and 0011 ' - 00 31' Southward position, in the Eastern of Kutai Kartanegara Regency. Generally, Muara Badak people's economic activity is fish farmerman and pond fish farmer. Speed boats are the main vehicle which is used to access sea and pond. Total number of fish farmer household is 1.457. Meanwhile, pond fish farmer household number is 1.766 and 270 of pool household.

There are 8 type of catching tools that are trammel net, trawl, gillnet, rakkang, rawai, bentang/original rawai, julu, pancing and jala.

Coverage area of productive pond culture is $4.808,80$ ha with 5.412 ton of total production. Whereas, production of sea fish and pond culture is $8.428,70$ ton and 63,22 ton, respectively. In detail, Muara Badak's household condition illustrate in the table 1 .

TABLE 1.

THE PROFILE OF CATCH AND CULTURE FISH FARMER HOUSEHOLD ON MUARA BADAK

\begin{tabular}{|c|c|}
\hline Fish farmer Household & Total \\
\hline \multicolumn{2}{|l|}{ The amount of boat } \\
\hline 1. Boat without engine & 326 unit \\
\hline 2. Boat with engine & 577 unit \\
\hline 3. $3.0-5 \mathrm{GT}$ & 1.531 unit \\
\hline 4. $5-10 \mathrm{GT}$ & - \\
\hline Catch fish production & $8.428,70$ ton \\
\hline \multicolumn{2}{|l|}{ Fish culture production } \\
\hline - $\quad$ Pond & 5.412 ton \\
\hline - $\quad$ Pool & 63,22 ton \\
\hline
\end{tabular}

Source : BPS Kabupaten Kutai Kartanegara, 2016.

\section{General Condition of Pond Productivity}

Pond is a main type of Mangrove land using. The rate of pond productivity of one pond to another pond can be different, its depend on production input such as the density of deployment, fertilizer amount and toxin.

The efficiency of production inputs usage in the shrimp pond led to optimization on shrimp growth.
Thus, it will be gained maximum yield. However, in the fact fish farmers often use some production input in a certain amount based only on habitual factors. They don't really consider about input usage proportion, input prices, and marginal product yielded.

There are two methods of input using by fish farmer, shrimp monoculture enterprise and shrimp and milk fish (Channus channus) policulture enterprise. The main type of shrimp is lobster, while spot shrimp is natural shrimp which is produced as the time of inducing water into pond, instead of deployment yield. Such spot shrimp is beneficial as an addition income for fish farmer.

\section{The Function of Production Analysis}

Determinant coefficient indicator (R2) use to assess whether Cob Douglas model which have been developed is fit enough for forecasting instrument (goodness of fit). Analysis result showed that the average values of production function determinant coefficient is 0,556 , it means that the seed deployment density, the amount of fertilizer and toxin can describe for 55,6\% shrimp pond production variation in the location of study, whereas $44, \%$ of the rest factors is caused by another factors which have not been included in the model.

The result of multiplied linear regression is intended to grasp the effect of independent variable to the yield of lobster production in Muara Badak, Kutai Kartanegara Regency. It can be seen in Table 2.

Regression analysis result can be formulated in the following formulation:

The coefficient of fertilizer factor is 0,115 , it means that the inclining of fertilizer usage for $1 \%$ will increase the yield for $11 \%$. Toxin factor do not significantly influence on production yield. Those are based on the indicator of value's significance which is greater than 5\%. Regression coefficient value of toxin usage is $-0,013$, it means that the increasing of toxin usage allocation for $1 \%$ will decrease the amount of production for $13 \%$. The result of partial test indicate that seed and fertilizer factors influence significantly on yield of production which can be seen on the significance's value under 0,05 . Regression coefficient value of 
seed is 0,333 , which show that the increasing of $1 \%$ fertilizer usage will increase the yield for $33 \%$ and conversely. It was based on the assumption of no factors will be changed.

Regarding to the result of profiling test (F-test) with $95 \%$ trust interval, the result is 12,946 on 0,00 significance level, it means that seeds factor, fertilizer and toxin influence simultaneously on the shrimp production yield in Muara Badak. It can be seen in the table 3 .

\section{E. Allocative efficiency analysis}

Efficiency test is used to see whether input or production factor which is used by shrimp pond enterprise in Muara Badak have been efficient or have not been efficient yet. Allocative efficiency is one of assessment type which can be used to know that efficiency.

Allocative efficiency of production factors usage on pond enterprise can be known through calculating the ratio of marginal product value and individually production factors prices. To analyze efficiency of individually production factors usage using regression coefficient value of CobbDouglass production function will emerge three possibilities, which are:

- If the efficiency value is more than 1 , mean that maximum efficiency has not achieved yet, thus production factors usage need to increase to reach efficient condition.

- If the efficiency value is equal to 1 , thus pond culture activities have reached efficient level.

- If efficiency value least than 1 , mean that pond culture activity has not reached efficient level, thus production factor usage should be decreased to reach efficient condition.

Regression analysis results show that toxin variable does not significantly affected on production yield. Seeds and fertilizer variable significantly affected to analyzed production. In the allocative efficiency analyze, analysis will be only conducted on variable which have a significant impact. The result of allocative efficiency analysis on production factors demonstrated in the table 4.

The value of ki on fertilizer usage were greater than 1 , that is 3,13 , its be shown on table 5.3 , mean that $1,26 \mathrm{~kg}$ fertilizer usage per acre were not efficient yet. To gain optimum fertilizer usage, it is need to add fertilizer usage, thus can increase fish farmer revenue. Based on analysis, optimum fertilizer usage is $11 \mathrm{~kg}$ per acre. Enhancement of pond productivity and nature seeds usage are the methods which can be done to increase production.

\section{F. Revenue Analysis}

[7], point out that revenue is the lag of total revenue and total expenses. Until today, pond is perceived as a main livelihood for the society of Muara Badak and around. The pond scale which are possessed by fish farmer household in this area is varied, it is range from 2 to 10 acres.

According to survey results, the majority of fish farmer around Muara Badak have a quite good production yield. It is proofed by the measurement results of the acquired production yield and the expensed cost. Based on survey and analysis results there are some fish farmer who have quite high profitability value, that is Rp. 6.408.066 per acre annually or Rp. 2.136 .022 per acre per production period.

According to analysis results, profit value, which has been acquired from this activity, is $\mathrm{Rp}$. 3.684.402/ha/year or Rp. 1.228.134/ha/production period. This profit is acquired by lessening revenue value with operational cost as along as production process. Such analysis results illustrate pond enterprise in this area is assured prospect as a local livelihood. This calculation could illustrate the cost and production of pond enterprise in Muara Badak, as be shown in the table 5 .

The high rate of dollar currency to rupiah influence directly to the increasing of shrimp price and the stability of shrimp demand in the international market. It makes such aquaculture enterprise remain as one of main livelihood for local people, with no consideration to some factors such as education, skill and knowledge level and also some problem which are faced in the pond culture enterprise due to its high-risk level to the death, such as illness, pest and weather.

\section{G. Revenue Cost Ratio (RCR) Analysis}

[7] said that RCR is a measurement tool to know whether enterprise is profitable or not. RCR analysis is an analysis mean to know relative benefit of an enterprise in the production period to 
the cost utilized in such activity. An enterprise could be interpreted as feasible if RCR is bigger than $1(\mathrm{RCR}>1)$. This illustrate that the higher is the RCR value, the higher is the benefit level of enterprise. The RCR value of shrimp pond enterprise in Muara Badak is 2,35. Its mean that this enterprise is feasible to run regarding $\mathrm{RCR}$ criteria $>1$, in other words, the benefit of pond culture enterprise in Muara Badak which have accepted is 2,35 times bigger than its cost.

\section{IV.SUMMARIES AND SUGGESTION}

Simultaneously, seeds factor (benur), fertilizer and toxin are significantly influenced on production yield. However, parsially seeds and fertilizer usage factors or variables influenced significantly on pond culture enterprise yield, while toxin factor is unsignificant.

The result of allocative efficiency test demonstrated seeds and fertilizers factors is inefficient yet. Therefore, it is need to add both seeds or fertilizer in each acre.

Muara Badak's Ponds productivity value is 17.66 , it is smaller than national standard productivity.

It is known that the result of pond culture enterprise in Muara Badak economic test is quite beneficial and feasible to run based on RCR indicator.

\section{SUGGESTIONS}

To increase the income, it is needed to optimalise pond culture enterprise by fish farmer through maximalizing usage and good management of production factors used.

The effort to increase pond productivity can be done through knowledge and skill enhancement for fish farmer.

It is needed a cooperation and synergic collaboration based on beneficial partnership principles in terms of providing production input, product marketing, financial and investment strengthening. Thus, fish farmer can work harder and diligently.

Government intervention is required to concern in supporting guidance and regulation. Therefore, fish farmer welfare is becoming true through increasing pond culture enterprise production and income.
TABLE 2. ESTIMATION RESULT AND REGRESSION TEST OF SHRIMP POND CULTURE ENTERPRISE FACTORS IN MUARA BADAK, 2016

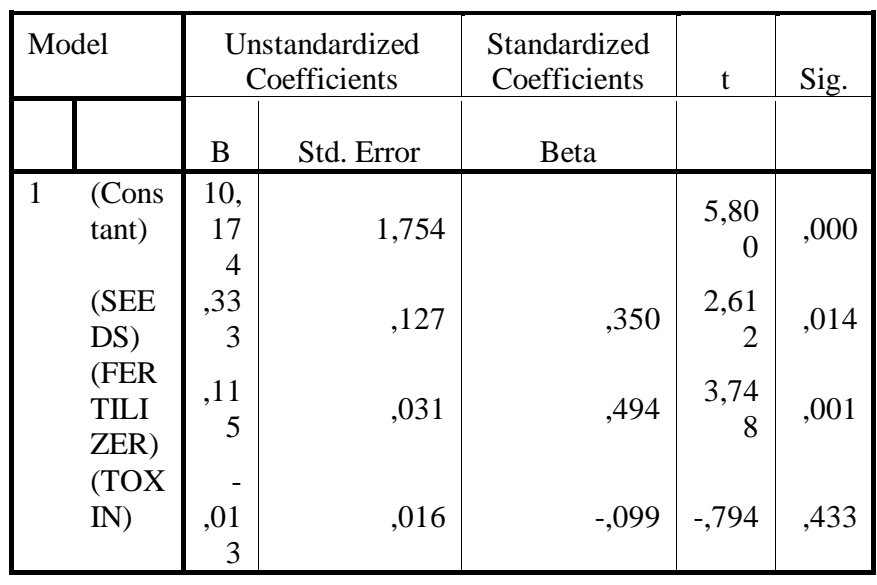

TABLE 3.

THE RESULT OF ANALYSIS OF VARIANCE

\begin{tabular}{lrrrrr}
\hline & \multicolumn{1}{c}{ Df } & $S S$ & $M S$ & $F$ & \multicolumn{2}{c}{ Significance } \\
& 3 & 10,335 & 3,445 & 12,946 &, $000(\mathrm{a})$ \\
Regression & 31 & 8,249 &, 266 & & \\
Residual & 34 & 18,584 & & & \\
Total & & & & \\
\hline
\end{tabular}

a Predictors: (Constant), TOXIN, FERTILIZER, SEEDS

b Dependent Variable: Y

TABLE 4.

THE ESTIMATION OF ALLOCATIVE EFFICIENCY VALUES OF SHRIMP POND CULTURE ENTERPRISE PRODUCTIONS FACTORS IN MUARA BADAK, 2015

\begin{tabular}{|c|c|c|c|c|c|c|c|c|}
\hline Variable & biX & $\bar{Y}$ & PY & $\overline{\mathbf{x}}$ & $\mathbf{P x}$ & $\overline{P M x}$ & NPMx & $\begin{array}{l}\text { NPMx/ } \\
\text { Px }\end{array}$ \\
\hline Seeds & 0,333 & $\begin{array}{l}17,6 \\
6\end{array}$ & 216.667 & 7835 & 35 & $\begin{array}{l}0,00 \\
75\end{array}$ & 162,74 & 4,65 \\
\hline Fertilizer & 0,115 & $\begin{array}{l}17,6 \\
6\end{array}$ & 216.667 & 1,26 & $\begin{array}{l}11 \\
1.3 \\
63\end{array}$ & $\begin{array}{l}1,61 \\
2\end{array}$ & $\begin{array}{l}349.229 \\
4\end{array}$ & 3,13 \\
\hline
\end{tabular}

Source. Processed data, 2016

TABLE 5. ECONOMIC DETAIL OF SHRIMP POND ENTERPRISE

\begin{tabular}{|l|c|}
\hline Description & Unit/Ha/Mp \\
\hline Shrimp average cost & Rp. 216.667 \\
\hline Production & 17,66 kilogram \\
\hline Revenue & Rp. 2.136 .022 \\
\hline Production cost & Rp. 907.888 \\
\hline Benefit & Rp. 1.228 .134 \\
\hline RCR & 2,35 \\
\hline
\end{tabular}

Source. Processed data, 2016

\section{REFERENCES}

[1] Dernberg, Thomas F, (1992), Konsep Teori dan Kebijakan Makroekonomi, penerjemah Karyaman Muchtar, Erlangga, Jakarta

[2] Dornbusch, Rudiger Dan Stanley Fischer, (1997), Makroekonomi, penerjemah Julius A. Mulyadi, Erlangga, Jakarta 
[3] Kusumawardhani, (2002), Efisiensi Ekonomi Usaha budidaya tambak udang Kubis (Di Kecamatan Bumaji, Kabupaten Malang), Agro Ekonomi Vol. 9 No. Jurusan Sosial Ekonomi Pertanian Fakultas Pertanian UGM.

[4] Miller, Roger LeRoy dan Roger E. Meiners, (2000), Teori Mikroekonomi Intermediate, penerjemah Haris Munandar, PT. Raja Grafindo Persada, Jakarta

[5] Mubyarto, (1999), Pengantar Ekonomi Pertanian, LP3ES, Jakarta.

[6] Salvatore D, (1997), Teori Ekonomi Mikro, penerjemah Drs. Rudi Sitompul, MA, Erlangga, Jakarta

[7] Soekartawi, (1990). Teori Ekonomi Produksi dengan Pokok Bahasan Analisis Fungsi Cobb-Douglas. Rajawali Press, Jakarta.

[8] , (1993). Prinsip Dasar Ekonomi Pertanian - Teori dan Aplikasi, PT. Raja Grafindo, Jakarta.
[9] Universitas Indonesia. Jakarta

[10] , (2000). Pembangunan Pertanian, Rajawali Press, Jakarta. (2002). Teori Ekonomi Produksi dengan pokok bahasan analisis fungsi Cobb-Douglas, Cetakan ke 3, Rajawali Pers, Jakarta.

[12] Sipahutar, Dorlan, (2000). Analisis Budidaya Ikan Sistem Karambadi Perairan Umum Kabupaten Kampar. Tesis S 2 UGM. Yogyakarta.

[13] Soedarsono, (1998), Pengantar Ekonomi Mikro, LP3ES, Jakarta

[14] Yotopoulos, Pan.A dan Jeffry B. Nugent, (1976). Economics Of Development :Empirical Investigations. Harper and Row Publisher, New York. 